\title{
PENGARUH KECANGGIHAN TEKNOLOGI INFORMASI, PARTISIPASI MANAJEMEN DAN KINERJA INDIVIDU TERHADAP EFEKTIVITAS SISTEM INFORMASI AKUNTANSI (Studi Empiris Pada PT. Sinar Di Kempas Jaya)
}

\author{
SURYANI \\ Universitas Islam Indragiri Tembilahan \\ Email: suryaniakt123@gmail.com
}

\begin{abstract}
This study aims to determine and empirically examine the effect of information technology sophistication, management participation and individual performance on the effectiveness of accounting information systems (empirical study at PT. Sinar Mas in Kempas Jaya). The population in this study were all employees at PT. Sinar Mas was crushed successfully. The sample selection was done by purposive sampling, from 50 questionnaires distributed, 49 respondents were obtained according to the criteria. The data analysis technique uses multiple linear regression with the data quality test used is the validity test and the reliability test. Classical assumption test used is normality test, multicollinearity test and heteoscedasticity test. The analytical test used is the t-test, F-test and the coefficient of determination $\left(R^{2}\right)$. Descriptive statistic was used to help analyze the data by describing the data that has been collected. The results of this study indicate that the sophistication of information technology has no effect on the effectiveness of accounting information systems, management participation has no effect on the effectiveness of accounting information systems, while individual performance has no effect on the effectiveness of accounting information systems. The value of $R^{2}$ or the coefficient of determination is 0.883 , which means that variations or changes in the dependent variable can only be explained by variations of the three independent variables, while $11.7 \%$ is explained by
\end{abstract} other causes outside the model or not being investigated.

Keywords : Information Technology Sophistication, Management Participation, Individual Performance and Effectiveness of Accounting Information Systems.

\section{ABSTRAK}

Penelitian ini bertujuan untuk mengetahui dan menguji secara empiris pengaruh kecanggihan teknologi informasi, partisipasi manajemen dan kinerja individu terhadap efektivitas sistem informasi akuntansi (studi empiris pada PT. Sinar Mas di Kempas Jaya). Populasi dalam penelitian ini adalah seluruh karyawan yang ada pada PT. Sinar Mas di Kempas Jaya. Pemilihan sampel dilakukan dengan cara purposive sampling, dari 50 kuesioner yang disebar diperoleh 49 responden yang sesuai kriteria. Teknik analisa data menggunakan regresi linear berganda dengan pengujian kualitas data yang digunakan adalah uji validitas dan uji reabilitas. Uji asumsi klasik yang digunakan adalah uji normalitas,uji multikolinearitas dan uji heteoskedastisitas. Uji analisa yang digunakan adalah uji-t, uji $\mathrm{F}$ dan uji koefisien determinasi $\left(\mathrm{R}^{2}\right)$. Statistik deskriptif digunakan untuk membantu menganalisis data dengan mendiskripsikan data yang telah terkumpul. Hasil penelitian ini menunjukan bahwa Kecanggihan Teknologi Informasi tidak berpengaruh terhadap Efektivitas Sistem Informasi Akuntansi, Partisipasi Manajemen berpengaruh terhadap Efektivitas Sistem Informasi Akuntansi, sedangkan Kinerja Individu tidak berpengaruh terhadap Efektivitas Sistem Informasi Akuntansi. Nilai $\mathrm{R}^{2}$ atau nilai koefisiensi determinasi sebesar 0,883 yang berarti variasi atau perubahan variabel dependen hanya mampu dijelaskan oleh variasi dari ketiga variabel independen , sedangkan 11,7\% dijelaskan sebab-sebab lain diluar model atau tidak diteliti.

Kata Kunci: Kecanggihan Teknologi Informasi, Partisipasi Manajemen, Kinerja Individu dan Efektivitas Sistem Informasi Akuntansi.

\section{PENDAHULUAN}

\subsection{Latar Belakang Masalah}

Kehidupan manusia sekarang, perlahan-lahan mulai mengalami perubahan. Perubahan ini disebabkan oleh salah satu faktor yang sangat mempengaruhi, yaitu adanya globalisasi. Salah satu dampak yang dirasakan dalam kehidupan manusia dengan adanya era globalisasi, globalisasi adalah perkembangan teknologi informasi. Teknologi informasi adalah sama dengan teknologi lainnya, hanya informasi merupakan komoditas yang diolah dengan teknologi tersebut. Disini ada globalisasi produk, jasa, pasar dan kompetisi yang semakin meningkat menuntut adanya fleksibilitas, kualitas, efektivitas biaya dan ketepatwaktuan. Kunci utama untuk mengetahui kebutuhan tersebut adalah efektivitas sistem informasi.

Dengan efektivitas sistem informasi akuntansi dapat menilai sejauh mana peningkatan-peningkatan pada saat ini. Perkembangan teknologi saat ini begitu pesat dan diiringi dengan perkembangan sistem informasi yang berbasis teknonologi. Hal ini menyebabkan terjadinya begitu cepat didalam berbagai bidang karna teknologi sangat dibutuhkan untuk membantu kegiatan-kegiatan usaha atau bisnis, dan mampu memberikan informasi yang akurat. Jika suatu entitas bisnis ingin menggunakan kecanggihan teknologi informasi sebagai pendukung kegiatan usahanya maka harus dilengkapi dengan infrastruktur teknologi informasi tersebut. Kemajuan teknologi informasi saat ini banyak membantu meningkatkan Sistem Informasi 
Akuntansi (SIA), dengan menggunakan komputer informasi atau alat teknologi yang lebih canggih yang akan disajikan lebih cepat, tepat dan akurat sehingga menghasilkan informasi yang lebih berkualitas.

Seiring dengan perkembangannya, sering kali kegiatan akuntansi menjadi sulit dilakukan oleh perusahan, karena permasalahan kompleksitas yang dialami oleh perusahaan tersebut berkaca pada permasalahan kompleksitas yang dialami oleh perusahaan, maka suatu teknologi diterapkan untuk memudahkan pekerjaan yang dilakukan manusia, yaitu dengan menggunakan komputer. Dalam keadaan seperti ini yang dialami oleh perusahaan mengenai sistem informasi akuntansi harus mampu mengendalikan sebagai sebuah prioritas utama. Partisipasi manajemen mempunyai peran yang penting dalam efektivitas sistem, partisipasi manajemen dalam memberikan dukungan suatu panduan mengenai komitmen dan dukungan atas segala sumber daya yang diperlukan oleh perusahaan.

Partisipasi manajemen sering disebut keterlibatan mental dan emosional seorang atau individu dalam situasi kelompok yang mendorong dia untuk berkontribusi terhadap tujuan kelompok dan mempertanggung jawabkan keterlibatannya. Partisipasi Manajemen merupakan manajemen yang ikut terlibat langsung dalam melakukan pelaksaan sistem informasi dan merencanakan strategi untuk meningkatkan sistem informasi yang akan digunakan.

Partisipasi manajemen diartikan sebagai keterlibatan dan keikutsertaan eksekutif atau manajemen dibidang teknologi informasi. Teknologi informasi dapat dimaanfatkan secara efektif, sehingga dapat memberikan konstribuai terhadap kinerja, maka karyawan dalam perusahan harus menggunakan teknologi tersebut dengan baik. kecanggihan manajemen pada dasarnya berhubungan dengan kecanggihan teknologi dalam merencanakan dan mengevaluasi aplikasi yang digunakan dalam usah kecil maupun besar. Peningkatan sistem informasi akuntansi memerlukan adanya partisipasi manajemen dalam mendukung implementasi dan pengembangan sistem informasi akuntansi, kegiatan oprasional perusahaan selalu melibatkan peran manajemen didalamnya. tetapi permasalahannya tidak jarang ditemukan bahwa teknologi yang diterapkan dalam sistem informasi sering tidak tepat atau tidak dimanfaatkan secara maksimal oleh individu pemakai sistem informasi, sehingga sistem informasi kurang memberikan manfaat dalam meningkatkan kinerja individual.

Kinerja individu sering dikatakan suatu hasil atau pencapaian kinerja individu yang merupakan target dari suatu tujuan yang harus tercapai (Suratini, 2015). Kinerja individu merupakan suatu pencapaian dari tugas-tugas dengan menggunakan teknologi informasi yang mendukung. Umumnya perusahaan mengharapkan kinerja yang baik dari masing-masing karyawan dalam mengerjakan tugas-tugas yang diberikan oleh perusahaan, namun sayang kinerja yang baik terkadang tidak diperoleh oleh perusahaan. Berdasarkan sebuah studi, salah satu faktor yang berpengaruh terhadap kinerja sumberdaya manusia adalah dari segi kepuasan kerjanya di perusahaan tersebut. Sayangnya masih minim upaya dari pihak perusahaan untuk dapat mengoptimalkan kinerja karyawan atau sumberdaya manusia.

Kinerja individu sangat dipengaruhi faktor kecanggihan teknologi yang akan membantu perusahan untuk menghasilkan informasi yang lebih akurat dan tepat waktu untuk mengambil keputusan yang efektif. Kecanggihan teknologi komputerisasi dapat diketahui atau dilihat dari perangkat lunak dan perangkat kerasnya, karena semakin canggih perangkat tersebut, maka dapat mendukung efektivitas dan kinerja sistem informasi akuntasi yang tentunya tetep memperhatikan kesesuaian kebutuhan akan teknologi tersebut untuk digunakan.

Efektivitas sistem informasi akuntansi merupakan suatu ukuran yang memberikan gambaran sejauh mana target dapat dicapai dari suatu kumpulan sumber daya yang diatur untuk mengumpulkan, memproses dan menyimpan data elektronik, kemudian mengubahnya menjadi sebuah informasi yang berguna serta menyediakan laporan formal yang dibutuhkan dengan baik secara kualitas maupun waktu. Sistem informasi akuntansi dikatakan efektif bila informasi yang diberikan oleh sistem tersebut dapat melayani kebutuhan pengguna sistem. Keuntungan utama dari pengguna optimal sistem informasi akuntansi dalam suatu perusahaan atau organisasi adalah adaptasi yang lebih baik terhadap lingkungan yang berubah, manajemen transaksi yang lebih baik dan tingkat daya saing yang tinggi.

Penelitian ini merupakan replikasi dari penelitian yang dilakukan oleh Safitri, dkk (2017) yang hasilnya penelitian menunjukkan bahwa kecanggihan teknologi informasi, partisipasi manajemen dan kinerja individu berpengaruh positif dan signifikan terhadap efektivitas sistem informasi akuntansi di Klinik Rancaekek Media 2 Kabupaten Bandung. Alasan melakukan replikasi penelitian dari Safitri, dkk (2017) karena seiring perkembangnya zaman, maka perkembangan teknologi informasi akan semakin canggih pula, hal ini akan berpengaruh terhadap Efektivitas Sistem Informasi Akuntansi yang diambil. Alasan meneliti di PT. Sinar Mas karena perusahaan memberikan konstribusi yang besar bagi masyarakat atau suskses mengelola bisnisnya, sehingga ini pantas diteliti karena adanya potensi pemimpinya sangat berperan penting dalam kesuksesan usaha tersebut.

\subsection{Perumusan Masalah}

Berdasarkan latar belakang penelitian yang dikemukakan di atas, maka masalah yang akan diteliti sebagai berikut:

1. Apakah kecanggihan teknolologi informasi berpengaruh terhadap efektivitas sistem informasi akuntansi pada PT. Sinar Mas di Kempas Jaya? 
2. Apakah partisipasi manajemen berpengaruh terhadap efektivitas sistem informasi akuntansi pada PT. Sinar Mas di Kempas Jaya?

3. Apakah kinerja individu berpengeruh terhadap efektifitas sistem informasi akuntansi pada PT. Sinar Mas di Kempas Jaya?

4. Apakah kecanggihan teknologi informasi, partisipasi manajemen dan kinerja individu berpengaruh terhadap efektivitas sistem informasi akuntansi pada PT. Sinar Mas di Kempas Jaya?

\section{TINJAUAN PUSTAKA}

\subsection{Kecanggihan Teknologi Informasi}

Kecanggihan teknologi informasi adalah merupakan jumlah aplikasi portofolio sistem informasi akuntasi yang diadopsi oleh perusahaan responden. Sutabri (2014) memberikan pengertian tentang teknologi sebagai pengembangan dan aplikasi dari alat, mesin, material dan proses yang menolong manusia menyelesaikan masalahnya, sedangkan informasi merupakan hasil pemerosesan, manipulasi, dan pengorganisasian penataan dari sekelompok data yang mempunyai nilai pengetahuan bagi penggunanya

\subsection{Partisipasi Manajemen}

Partisipasi Manajemen merupakan manajemen yang ikut terlibat langsung dalam melakukan pelaksaan sistem informasi dan merencanakan strategi untuk meningkatkan sistem informasi yang akan digunakan. Intinya adalah bagaimana sebuah proyek atau pekerjaan melibatkan semua unsur yang ada dalam kelompok. Dukungan yang akan diberikan manajemen menjadi sebagai pedoman dalam menerapkan komitmen dan dukungan atas berbagai sumber daya yang dibutuhkan bagi perusahaan (Ratnaningsih dan Suaryana, 2015).

\subsection{Kinerja Individu}

Kinerja individu merupakan hasil kerja perseorangan anggota organisasi atau karyawan perusahaan. Pencapaian tujuan suatu organisasi sangat dipengaruhi oleh sumber daya yang terdapat dalam organisasinya, termasuk anggota yang memiliki peran aktif sebagai pelaku dalam upaya mencapai tujuan organisasi tersebut. Pengukuran kinerja dilakukan dengan mengumpulkan, menganalisis dan melaporkan berbagai informasi yang berhubungan dengan tingkat kerja dari individu, devisi, atau perusahaan (Soemohadiwidjojo, 2015).

\subsection{Efektivitas Sistem Informasi Akuntansi}

Efektivitas sistem informasi akuntansi merupakan suatu ukuran yang menyatakan seberapa jauh target (kuantitas, kualitas dan waktu) yang telah dicapai oleh pihak manajemen. Efektivitas sistem informasi akuntansi. Menurut Bodnar \& Hopwood (2014) sekumpul sumber dana dan daya (resources), seperti orang, teknologi dan peralatan yang dirancang untuk mentransformasi data keuangan dan data lainnya menjadi informasi. Informasi ini dikomunikasikan kepada para pengambilan keputusan yang sangat beragam. Sistem informasi akuntansi menurut Susanto (2013) merupakan kumpulan (integritas) dari sub-sub/komponen baik fisik maupun nonfisik yang saling berhubungan dan bekerja sama satu sama lain secara harmonis untuk mengelolah data transaksi yang berkaitan dengan masalah keuangan menjadi informasi keuangan.

\subsection{Kerangka Pemikiran}

Gambar 2.1

\section{Kerangka Pemikiran}

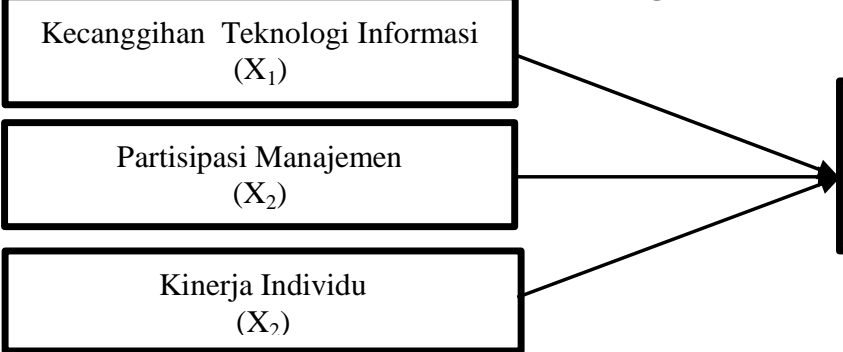

Variabel Independen
Efektivitas Sistem Informasi Akuntansi

(Y)

\subsection{Hipotesa}

Berdasarkan kerangka pikiran di atas maka peneliti merumuskan hipotesa sebagai berikut:

$\mathrm{H}_{1}$ : Kecanggihan Teknologi Informasi berpengaruh terhadap Efektivitas Sistem Informasi Akuntansi pada PT. Sinar Mas Dikempas Jaya.

$\mathrm{H}_{2}$ : Partisipasi Manajemen berpengaruh terhadap Efektivitas Sistem Informasi Akuntansi pada PT. Sinar Mas Dikempas Jaya.

$\mathrm{H}_{3}$ : Kinerja Individu berpengaruh terhadap Efektivitas Sistem Informasi Akuntansi pada PT. Sinar Mas Dikempas Jaya.

$\mathrm{H}_{4}$ : Kecanggihan Teknologi Informasi, Pelindungan Sistem Informasi, Dan Pengetahuan Manajer berpengaruh terhadap Efektivitas Sistem Informasi Akuntansi pada Pt. Sinar Mas Dikempas Jaya. 


\section{METODOLOGI PENELITIAN}

\subsection{Rancangan Penelitian}

Penelitian ini termasuk penelitian kuantitatif yang bertujuan menguji hipotesis. Rancangan penelitian yang akan digunakan dalam penelitian ini yaitu penelitian deskriptif (descriptif research), merupakan penelitian terhadap masalah-masalah berupa fakta-fakta saat ini dari suatu populasi. Tujuan dari penelitian deskriptif adalah untuk menguji hipotesis atau menjawab pertanyaan yang berkaitan dengan current status dari subyek yang diteliti (Indriantoro, 2016). Dalam penelitian ini ada tiga variabel independen yakni kecanggihan teknologi informasi, partisipasi manajemen dan kinerja individu sedangkan variabel dependennya efektivitas sistem informasi akuntansi.

\subsection{Tempat dan Waktu Penelitian}

Penelitian ini akan dilakukan pada PT. Sinar Mas di Kempas Jaya Kabupaten Indragiri Hilir. Waktu yang digunakan untuk melakukan penelitian ini selama 3 bulan yaitu dari bulan Desember 2019 sampai dengan februari 2020 yang dimulai dari tahap survey tempat penelitian, tahap proses perizinan dan tahap terakhir adalah proses pengolahan data.

\subsection{Populasi dan Sampel}

Menurut Sugiyono (2016), populasi adalah wilayah generalisasi yang terdiri atas objek yang mempunyai kualitas dan karakteristik tertentu yang ditetapkan oleh peneliti untuk dipelajari dan kemudian ditarik kesimpulannya. Populasi dalam penelitian ini adalah seluruh karyawan yang ada pada PT. Sinar Mas di Kempas Jaya.

Sampel adalah bagian dari jumlah dan karakteristik yang dimiliki oleh populasi tersebut (Indirantoro dan Supomo, 2016). Sampel dalam penelitian ini mengunakan sampel non probabilitas yaitu elemen-elemen populasi yang tidak mempunyai kesempatan yang sama untuk di pilih menjadi sampel. Metode penentuan sampel dalam penelitian ini mengunakan instrumen berupa kuesioner dan skala yang digunakan dalam penyusunan kuesioner adalah skala likert, sedangkan teknik pengambilan sampling menggunakan purposive sampling yaitu pemilihan secara tidak acak yang informasinya diperoleh dengan menggunakan kreteria tertentu (indriantoro, 2016). Adapun krekteria yang digunakan adalah sebagai berikut:

1. Karyawan tetap PT. Sinar Mas di Kempas Jaya.

2. Karyawan yang sudah bekerja minimal 2 tahun pada PT. Sinar Mas di Kempas Jaya.

3. Karyawan yang memiliki jenjang pendidikan paling rendah minimal SLTA.

\subsection{Prosedur Pengumpulan Data}

Pengumpulan data dilakukan untuk memperoleh informsi yang dibutuhkan dalam rangka mencapai tujuan penelitian. Sebelum melakukan penelitian, seorang peneliti biasanya telah memiliki dugaan berdasarkan teori yang ia gunakan, dugaan tersebut disebut dengan hipotesis. Prosedur pengumpulan data dalam penelitian ini adalah dengan menggunakan teknik kuesioner. Data penelitian ini berupa data primer yang dikumpulkan menggunakan kuesioner yang dibagikan secara langsung kepada karyawan PT. Sinar Mas di Kempas Jaya. Skala pengukuran yang digunakan dalam penelitian ini adalah skala likert.

\subsection{Definisi Operasional dan Pengukuran Variabel}

\subsubsection{Variabel Independen}

\section{Kecanggihan Teknologi Informasi $\left(\mathbf{X}_{1}\right)$}

Raymond dan Pare (2016) mendefinisikan bahwa kecanggihan teknologi informasi sebagai suatu konstruksi yang mengacu pada penggunaan alam, kompleksitas dan saling ketergantungan teknologi informasi dan manajemen dalam suatu organisasi. Untuk menentukan keberhasilan perusahaan yang bekelanjutan, maka perusahaan membutuhkan teknologi informasi agar lebih mempercepat memperoleh informasi tepat, cepat dan akurat. Adapun indikator kecanggihan teknologi informasi, partisipasi manajemen, pengetahuan manajer akuntansi dan kualitas informasi akuntansi. Variabel dalam penelitian ini diukur dengan menggunakan 5 (lima) skala likert.

\section{Partisipasi Manajemen $\left(\mathbf{X}_{2}\right)$}

Partisipasi Manajemen merupakan manajemen yang ikut terlibat langsung dalam melakukan pelaksaan sistem informasi dan merencanakan strategi untuk meningkatkan sistem informasi yang akan digunakan. Dukungan yang akan diberikan manajemen menjadi sebagai pedoman dalam menerapkan komitmen dan dukungan atas berbagai sumber daya yang dibutuhkan bagi perusahaan Ratnaningsih dan Suaryana (2015).

Penelitian ini menggunakan kuesioner oleh Ismail (2011) dengan 16 item pertanyaan. Adapun indikator dalam variabel ini adalah pemilihan perangkat keras dan perangkat lunak, implementasi sistem, pemeliharaan sistem dan pemecahan masalah, dan pemecahan untuk pengembangan lebih lanjut. Variabel dalam penelitan adalah diukur dengan menggunakan 5 (lima) skala likert. 


\section{Kinerja Individu $\left(\mathbf{X}_{3}\right)$}

Kinerja individu adalah suatu hasil atau pencapaian kinerja individu yang merupakan target dari suatu tujuan yang harus tercapai (Suratini, 2015). Adapun indikator dalam panelitian ini adalah pendidikan, pelatihan, pengalaman kerja, insentif. Variabel dalam penelitian adalah diukur dengan menggunakan 5 (lima) skala likert.

\subsubsection{Variabel Dependen}

1. Efektivitas Sistem Informasi Akuntansi (Y)

Efektivitas sistem informasi akuntansi adalah sekumpul sumber dana dan daya (resources), seperti orang dan peralatan yang dirancang untuk mentransformasi data keuangan dan data lainnya menjadi informasi (Bodnar \& Hopwood, 2014). Adapun indikator dalam penelitian ini adalah pemanfaatan teknologi informasi, kompetensi sumber daya manusia dan Efektivitas Sistem Informasi Akuntansi. Variabel dalam penelitan adalah diukur dengan menggunakan 5 (lima) skala likert

\subsection{Teknik Analis Data}

Metode yang digunakan dalam penelitian ini adalah metode penelitian kuantitatif, yaitu metode penelitian dengan menggunakan kuesioner untuk mempermudah analisa atas masalah yang diteliti. Tujuan dari analisa data adalah untuk mendapatkan informasi relevan yang terkandung dalam data tersebut dan menggunakan hasilnya untuk memecahkan suatu masalah (Ghozali, 2011). Analisis data dengan menggunakan program SPSS (Statistical Product And Service Solution) versi 26,0 yang merupakan salah satu aplikasi komputer untuk menganalisis data statistik.

\section{HASIL PENELITIAN DAN PEMBAHASAN \\ 4.1 Hasil Penelitian \\ 1. Statistik Deskriptif}

Tabel 4.1

Hasil Statistik Deskriptif

Descriptive Statistics

\begin{tabular}{|l|r|r|r|r|r|r|r|}
\hline & \multicolumn{1}{|c|}{$\mathrm{N}$} & \multicolumn{1}{c|}{ Range } & \multicolumn{1}{c|}{ Min } & \multicolumn{1}{c|}{ Max } & \multicolumn{1}{c|}{ Mean } & Std. Deviation & Variance \\
\hline $\begin{array}{l}\text { Kecanggihan Teknologi } \\
\text { Informasi }\end{array}$ & 49 & 18,00 & 22,00 & 40,00 & 37,0612 & 4,06411 & 16,517 \\
\hline Partisipasi Manajemen & 49 & 16,00 & 64,00 & 80,00 & 74,2041 & 3,81324 & 14,541 \\
\hline Kinerja Individu & 49 & 10,00 & 20,00 & 30,00 & 28,0000 & 2,51661 & 6,333 \\
\hline $\begin{array}{l}\text { Efektivitas Sistem } \\
\text { Informasi Akuntansi }\end{array}$ & 49 & 11,00 & 34,00 & 45,00 & 41,6735 & 2,74915 & 7,558 \\
\hline Valid N (Listwise) & 49 & & & & & & \\
\hline
\end{tabular}

\section{Sumber : Hasil Olahan SPSS Versi 26, 2020}

Dari hasil 4.1 dapat dilihat jumlah data $(\mathrm{N})$ yang valid 49, nilai minimum dari data Kecanggihan Teknologi Informasi adalah 22,00, Nilai minimum dari data Partisipasi Manajemen adalah 64,00, Kinerja Individu sebesar 20,00 dan Efektivitas Sistem Informasi Akuntansi 34,00. Nilai maksimum Kecanggihan Teknologi Informasi adalah 40,00, Partisipasi Manajemen sebesar 80,00, Nilai maksimum Kinerja Individu adalah 30,00, dan Nilai maksimum dari data Efektivitas Sistem Informasi Akuntansi adalah 45,00. Nilai ratarata (mean) Kecanggihan Teknologi Informasi sebesar 37,0612, nilai rata-rata (mean) Partisipasi Manajemen adalah 74,2041, Nilai rata-rata (mean) Kinerja Individu 28,0000. Nilai rata-rata (mean) Efektivitas Sistem Informasi Akuntansi adalah 41,6735, Standar Deviasi dari variabel Kecanggihan Teknologi Informasi sebesar 4,06411. Deviasi Standar dari variabel Partisipasi Manajemen adalah 3,81324. Deviasi Standar Kinerja Individu sebesar 2,51661 dan Deviasi Standar dari variabel Efektivitas Sistem Informasi Akuntansi adalah 2,74915 .

\section{Uji Validitas}

Tabel 4.2

Hasil Uji Validitas Kecanggihan Teknologi Informasi $\left(\mathbf{X}_{1}\right)$

\begin{tabular}{|l|l|l|l|}
\hline Item Pertanyaan & r hitung & r tabel & Keterangan \\
\hline 1 & 0,523 & 0,281 & Valid \\
\hline 2 & 0,935 & 0,281 & Valid \\
\hline 3 & 0,428 & 0,281 & Valid \\
\hline 4 & 0,428 & 0,281 & Valid \\
\hline 5 & 0,523 & 0,281 & Valid \\
\hline 6 & 0,935 & 0,281 & Valid \\
\hline 7 & 0,935 & 0,281 & Valid \\
\hline 8 & 0,935 & 0,281 & Valid \\
\hline
\end{tabular}

Sumber : Hasil Olahan SPSS Versi 26, 2020

Suryani, Pengaruh Kecanggihan Teknologi Informasi, Partisipasi Manajemen Dan Kinerja Individu Terhadap Efektivitas Sistem Informasi Akuntansi 
Dari hasil menunjukkan nilai person correlation ( $\mathrm{r}$ hitung) untuk setiap item pertanyaan lebih besar dari nilai $\mathrm{r}$ tabel. Hal ini menunjukkan berarti bahwa semua indikator/ item pertanyaan yang mengukur variabel Kecanggihan Teknologi Informasi valid

Tabel 4.3

Hasil Uji Partisipasi Manajemen $\left(\mathbf{X}_{2}\right)$

\begin{tabular}{|l|l|l|l|}
\hline Item Pertanyaan & r hitung & r tabel & Keterangan \\
\hline 1 & 0,451 & 0,281 & Valid \\
\hline 2 & 0,520 & 0,281 & Valid \\
\hline 3 & 0,305 & 0,281 & Valid \\
\hline 4 & 0,556 & 0,281 & Valid \\
\hline 5 & 0,398 & 0,281 & Valid \\
\hline 6 & 0,297 & 0,281 & Valid \\
\hline 7 & 0,288 & 0,281 & Valid \\
\hline 8 & 0,418 & 0,281 & Valid \\
\hline 9 & 0,451 & 0,281 & Valid \\
\hline 10 & 0,520 & 0,281 & Valid \\
\hline 11 & 0,305 & 0,281 & Valid \\
\hline 12 & 0,556 & 0,281 & Valid \\
\hline 13 & 0,398 & 0,281 & Valid \\
\hline 14 & 0,297 & 0,281 & Valid \\
\hline 15 & 0,288 & 0,281 & Valid \\
\hline 16 & 0,418 & 0,281 & Valid \\
\hline
\end{tabular}

Sumber : Hasil Olahan SPSS Versi 26, 2020

Dari hasil menunjukkan nilai person correlation ( $\mathrm{r}$ hitung) untuk setiap item pertanyaan lebih besar dari nilai $r$ tabel. Hal ini berarti bahwa semua indikator/ item pertanyaan yang mengukur variabel Partisipasi Manajemen adalah valid karna nilai $r$ hitung yang dihasilkan lebih besar dari $r$ tabel 0,281

Tabel 4.4

Hasil Uji Validitas Kinerja Individu $\left(\mathbf{X}_{3}\right)$

\begin{tabular}{|l|l|l|l|}
\hline Item Pertanyaan & r hitung & r tabel & Keterangan \\
\hline 1 & 0,598 & 0,281 & Valid \\
\hline 2 & 0,820 & 0,281 & Valid \\
\hline 3 & 0,620 & 0,281 & Valid \\
\hline 4 & 0,620 & 0,281 & Valid \\
\hline 5 & 0,598 & 0,281 & Valid \\
\hline 6 & 0,820 & 0,281 & Valid \\
\hline
\end{tabular}

Sumber : Hasil Olahan SPSS Versi 26, 2020

Dari hasil menunjukkan nilai person correlation ( $\mathrm{r}$ hitung) untuk setiap item pertanyaan lebih besar dari nilai $\mathrm{r}$ tabel. Hal ini berarti bahwa semua indikator/ item pertanyaan yang mengukur variabel Kinerja Individu adalah valid karna nilai $r$ hitung yang dihasilkan lebih besar dari $r$ tabel 0,281.

Tabel 4.5

Hasil Uji Validitas Efektivitas Sistem Informasi Akuntansi (Y)

\begin{tabular}{|l|l|l|l|}
\hline Item Pertanyaan & r hitung & r tabel & Keterangan \\
\hline 1 & 0,512 & 0,281 & Valid \\
\hline 2 & 0,685 & 0,281 & Valid \\
\hline 3 & 0,323 & 0,281 & Valid \\
\hline 4 & 0,590 & 0,281 & Valid \\
\hline 5 & 0,512 & 0,281 & Valid \\
\hline 6 & 0,685 & 0,281 & Valid \\
\hline 7 & 0,323 & 0,281 & Valid \\
\hline 8 & 0,590 & 0,281 & Valid \\
\hline 9 & 0,296 & 0,281 & Valid \\
\hline
\end{tabular}

Sumber : Hasil Olahan SPSS Versi 26, 2020

Dari hasil menunjukkan nilai person correlation ( $\mathrm{r}$ hitung) untuk setiap item pertanyaan lebih besar dari nilai $r$ tabel. Hal ini berarti bahwa semua indikator/ item pertanyaan yang mengukur variabel Efektivitas Sistem Informasi Akuntansi adalah valid karena nilai $r$ hitung yang dihasilkan lebih besar dari $r$ tabel 0,281.

\section{Uji Reliabilitas}

Penguji reliabilitas dalam penelitian ini menggunakan koefisien croncbach alpha dimana suatu variabel dinyatakan reliabel bila memberikan nilai cronbach alpa di atas angka 0,60 .

Suryani, Pengaruh Kecanggihan Teknologi Informasi, Partisipasi Manajemen Dan Kinerja Individu Terhadap Efektivitas Sistem Informasi Akuntansi 
Tabel 4.6

Hasil Uji Reliabilitas Variabel Penelitian

\begin{tabular}{|l|c|c|l|}
\hline Variabel & Conbraca Alpha & Level Compraca Alpha & Keterangan \\
\hline Kecanggihan TI & .871 & 0,60 & Realibel \\
\hline Partisipasi Manajemen & .645 & 0,60 & Realibel \\
\hline Kinerja Individu & .742 & 0,60 & Realibel \\
\hline Efektivitas SIA & .612 & 0,60 & Realibel \\
\hline
\end{tabular}

Sumber : Hasil Olahan SPSS Versi 26, 2020

\section{Uji Normalitas}

Dalam penelitian ini, uji normalitas dilakukan dengan menggunakan grafik normal probability plost dan uji Kolmogorov-Smirnov dengan tingkat signifikansi 0,05 atau 5\%.

\section{Tabel 4.7}

Hasil Uji Normalitas

\begin{tabular}{|l|l|r|}
\hline \multicolumn{2}{|l|}{ One-Sample Kolmogorov-Smirnov Test } \\
\hline N & Studentized Deleted Residual \\
\hline \multirow{2}{*}{ Normal Parameters } \\
& Mean & 49 \\
\cline { 2 - 3 } & Std. Deviation & -.0067531 \\
\hline \multirow{2}{*}{ Most Extreme Differences } & Absolute & 1.02463555 \\
\cline { 2 - 3 } & Positive & .080 \\
\cline { 2 - 3 } & Negative & .056 \\
\hline Test Statistic & -.080 \\
\hline Asymp. Sig. (2-tailed) & .080 \\
\hline
\end{tabular}

Sumber : Data Olahan SPSS 26, 2020

Nilai signifikansi hasi uji kolmogorov smirnov untuk masing-masing variabel peneltian dengan signifikasi adalah 0,200 dan nilai Kolmogorov Smirnov adalah 0,080 yang lebih besar dari 0,05 sehingga dapat disimpulkan bahwa distribusi data penelitian adalah normal.

\section{Gambar 4.1}

\section{Hasil Uji Normalitas}

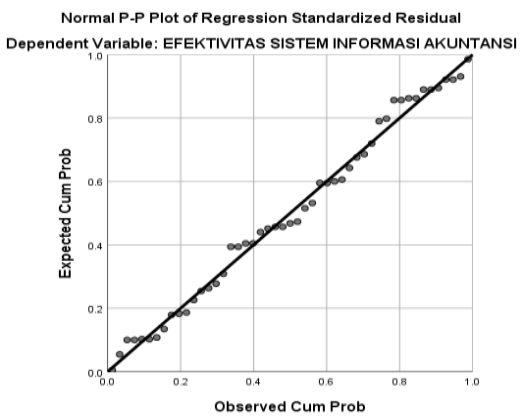

Sumber : Data Olahan SPSS 26,2020

Dari grafik histogram pada gambar 4.1 menunjukkan titik-titik menyebar disekitar garis diagonal maka dapat disimpulkan bahwa model regrsi layak digunakan karena memenuhi uji normalitas data.

\section{Uji Multikolinieritas}

Pengujian ada atau tidaknya multikolinieritas didalam model regresi dapat dilakukan dengan melihat nilai tolerance dan nilai variance inflation factor (VIF). Nilai yang umum dipakai untuk menunjukkan adanya multikolinieritas adalah tolerance $>0,10$ atau VIF $<10$.

Tabel 4.8

Hasil Uji Multikolinieritas

\begin{tabular}{|c|c|c|c|c|c|c|c|c|}
\hline \multicolumn{9}{|c|}{ Coefficients $^{\mathrm{a}}$} \\
\hline & \multirow[b]{2}{*}{ Model } & \multicolumn{2}{|c|}{$\begin{array}{l}\text { Unstandardized } \\
\text { Coefficients }\end{array}$} & \multirow{2}{*}{$\begin{array}{c}\begin{array}{c}\text { Standardized } \\
\text { Coefficients }\end{array} \\
\text { Beta } \\
\end{array}$} & \multirow[b]{2}{*}{$\mathrm{t}$} & \multirow[b]{2}{*}{ Sig. } & \multicolumn{2}{|c|}{ Collinearity Statistics } \\
\hline & & $\mathrm{B}$ & Std. Error & & & & Tolerance & VIF \\
\hline 1 & (Constant) & -1.693 & 6.392 & & -.265 & .792 & & \\
\hline & $\begin{array}{l}\text { Kecanggihan Teknologi } \\
\text { Nformasi }\end{array}$ & -.110 & .072 & -.142 & -1.527 & .134 & .527 & 1.897 \\
\hline & Partisipasi Manajemen & 693 & .068 & .962 & 10.242 & .000 & .515 & 1.941 \\
\hline & Kinerja Individu & -.142 & 155 & -.066 & -.917 & .364 & .891 & 1.123 \\
\hline
\end{tabular}

a. Dependent Variable: Efektivitas Sistem Informasi Akuntansi

Sumber : Hasil Olahan SPSS Versi 26, 2020

Suryani, Pengaruh Kecanggihan Teknologi Informasi, Partisipasi Manajemen Dan Kinerja Individu Terhadap Efektivitas Sistem Informasi Akuntansi 
Berdasarkan uji yang dilakukan dimana hasil menunjukkan bahwa variabel bebas yaitu Kecanggihan Teknologi Informasi bernilai sebesar 1.897, Partisipasi Manajemen sebesar 1.941 dan Kinerja Individu 1.123 memiki angka variance inflaction factor (VIF) dibawah angka 10. Dengan demikan disimpulakan persamaan regresi yang dapat dipakai sebagai model analisa tidak terdapat persoalan multikolonearitas.

\section{Uji Heterokedastisitas}

Penguji ini dilakukan dengan metode grafik yaitu dengan melihat ada tidaknya pada tertentu yang tergambar pada scatterplot. Dari data yang diolah menggunakan SPPS dengan uji heterokedastisitas sebagai berikut.

Gambar. 4.2

Kurva P Plot Heterokedastisitas

Scatterplot

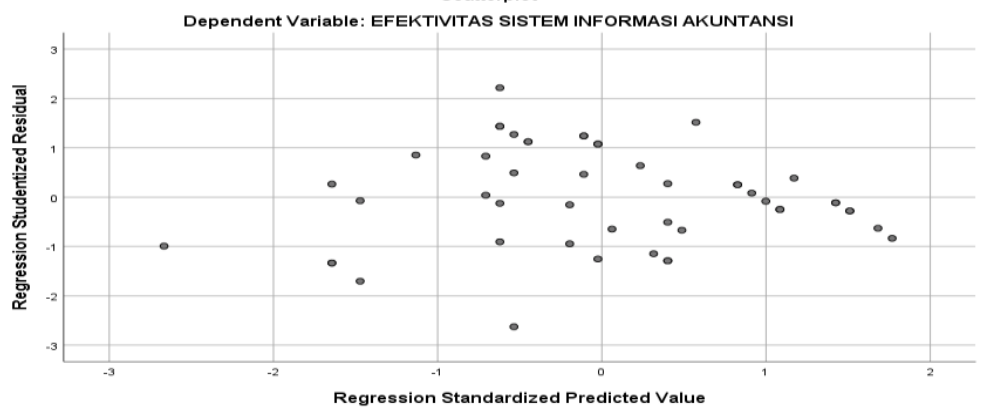

Sumber : Data Olahan SPSS 26, 2020

Hasil pengujian heterokedastisitas pada penelitian ini menggunakan software SPSS dengan cara mengamati pola yang terdapat pada scatter plot, yang hasilnya terlihat bahwa titik menyebar secara acak, walaupun tidak semuanya, tidak membentuk sebuah pola tertentu yang jelas, serta tersebar baik diatas maupun dibawah angka nol pada sumbu Y. Hal ini berarti tidak terjadi heterokedatisitas pada model regresi, sehingga model regresi layak dipakai.

\section{Uji Regresi Berganda}

Analisis regresi berganda bertujuan untuk mengetahui ada tidaknya pengaruh variabel independen yaitu kecanggihan teknologi informasi, partisipasi manajemen, dan kinerja individu terhadap dependen efektivitas sistem informasi akuntansi. Dengan menggunakan SPSS 26. maka dapat diolah untuk dapat menunjukkan adanya pengaruh atau tidak antara variabel independen (Kecanggihan Teknologi Informasi, Partisipasi Manajemen, dan Kinerja Individu) dengan variabel dependen (Efektivitas Sistem Informasi Akuntansi).

Tabel 4.9

Hasil Uji Regresi Berganda

\begin{tabular}{|c|c|c|c|c|c|c|}
\hline \multicolumn{7}{|c|}{ Coefficients $^{\mathrm{a}}$} \\
\hline \multirow{2}{*}{\multicolumn{2}{|c|}{ Model }} & \multicolumn{2}{|c|}{$\begin{array}{l}\text { Unstandardized } \\
\text { Coefficients }\end{array}$} & \multirow{2}{*}{$\begin{array}{c}\text { Standardized } \\
\text { Coefficients }\end{array}$} & \multirow[b]{2}{*}{$\mathrm{t}$} & \multirow[b]{2}{*}{ Sig. } \\
\hline & & $\mathrm{B}$ & Std. Error & & & \\
\hline \multirow[t]{4}{*}{1} & (Constant) & -1.693 & 6.392 & & -.265 & .792 \\
\hline & $\begin{array}{l}\text { Kecanggihan Teknologi } \\
\text { Nformasi }\end{array}$ & -.110 & .072 & -.142 & -1.527 & .134 \\
\hline & Partisipasi Manajemen & .693 & .068 & .962 & 10.242 & .000 \\
\hline & Kinerja Individu & -.142 & .155 & -.066 & -.917 & .364 \\
\hline
\end{tabular}

a. Dependent Variable: Efektivitas Sistem Informasi Akuntansi

Sumber : Data Olahan SPSS 26, 2020

Dari tabel uji regresi berganda di atas maka diperoleh persamaan regresi berganda sebagai berikut:

$$
Y=1,693-0,110 X_{1}+0,693 X_{2}-0,142 X_{2}+\varepsilon
$$

\section{Uji Parsial (Uji t)}

Uji-t dilakukan untuk menguji seberapa jauh pengaruh suatu variabel indipenden dan menjelaskan variabel dependen. Uji-t dilihat dari signifikansi, jika nilai signifikansi $<0,05$, maka variabel independen tidak berpengaruh terhadap variabel dependen.

Berdasarkan hasil uji-t pada tabel 4.9 menunjukkan bahwa variabel kecanggihan teknologi informasi memiliki nilai $t_{\text {hitung }}$ sebesar $-1,527$ lebih kecil dari nilai $t_{\text {tabel }}$ sebesar 2,0128 dan tingkat signifikansi 0,134 lebih besar dari tingkat signifikan yang ditetapkan adalah 0,05 , maka $\mathrm{H}_{1}$ ditolak sehingga dapat disimpulkan bahwa kecanggihan teknologi informasi tidak berpengaruh terhadap efektivitas sistem informasi akuntansi. 
Varibel partisipasi manajemen pada tabel 4.9 menunjukkan bahwa memiliki $\mathrm{t}_{\text {hitung }}$ sebesar 10,242 lebih besar dari nilai $\mathrm{t}_{\text {tabel }}$ sebesar 2,0128 dan tingkat signifikan sebesar 0,00 lebih kecil dari tingkat signifikan yang ditetapkan adalah 0,05 , maka $\mathrm{H}_{2}$ diterima sehingga dapat disimpulkan bahwa partisipasi manajemen berpengaruh terhadap efektivitas sistem informasi akuntansi.

Variabel kinerja individu pada tabel 4.9 menunjukkan nilai $t_{\text {hitung }}-0,917$ lebih kecil dari nilai $t_{\text {tabel }}$ sebesar 2,0128 dan tingkat signifikan sebesar 0,364 lebih besar dari tingkat signifikan yang ditetapkan adalah 0,05, maka $\mathrm{H}_{3}$ diterima sehingga dapat disimpulkan bahwa kinerja individu tidak berpengaruh terhadap efektifitas sistem informasi akuntansi.

\section{Uji Simultan (Uji F)}

Uji $\mathrm{F}$ bertujuan untuk mengetahui bahwa variabel independen (Kecanggihan Teknologi Informasi, Partisipasi Manajemen dan Kinerja Individu) secara simultan mempunyai pengaruh yang signifikan terhadap variabel dependen (Evektifitas Sistem Informasi Akuntansi).

Tabel. 4.10

Hasil Uji F (Simultan)

\begin{tabular}{|l|l|r|r|r|r|c|}
\hline \multicolumn{7}{|c|}{ MNOVA $^{\mathrm{a}}$} \\
\hline \multirow{3}{*}{ Model } & $\begin{array}{c}\text { Sum of } \\
\text { Squares }\end{array}$ & Df & Mean Square & F & \multicolumn{1}{c|}{ Sig. } \\
\hline 1 & Regression & 322,877 & 3 & 107,626 & 121,388 &, $000^{\mathrm{b}}$ \\
\cline { 2 - 8 } & Residual & 39,898 & 45 &, 887 & & \\
\cline { 2 - 8 } & Total & 362,776 & 48 & & & \\
\hline
\end{tabular}

a. Dependent Variable: Efektivitas Sistem Informasi Akuntansi

b. Predictors: (Constant), Kinerja Individu, Partisipasi Manajemen, Kecanggihan

Teknologiinformasi

Sumber : Data Olahan SPSS 26, 2020

Dapat diketahui hasil uji anova (analysis of varians) atau uji $\mathrm{F}$, menunjukkan bahwa nilai $\mathrm{F}_{\text {hitung }}$ sebesar 121,388 sedangkan $\mathrm{F}_{\text {tabel }}$ sebesar 2,81 dengan df pembimbing= 3, df penyebut $=45$ dan tarif signifikan $\alpha=0,05$ sehingga $F_{\text {hitung }}>F_{\text {tabel }}$ dan signifikan sebesar $0,000<0,05$. Hal ini mengindikasikan bahwa Kecanggihan Teknologi Informasi, Partisipasi Manajemen, dan Kinerja Individu secara bersama-sama berpengaruh signifikan terhadap Efektifitas Sistem Informasi Akuntansi pada PT. Sinar Mas di Kempas Jaya, sehingga $\mathrm{H}_{4}$ diterima.

\section{Uji Koefisien Determinasi $\left(\mathbf{R}^{2}\right)$}

Analisis terhadap nilai koefisien determinasi dilakukan untuk mengetahui seberapa besar kemampuan variabel independen dalam menjelaskan variasi yang terjadi dalam variabel dependen. Hasil uji koefisien determinasi $\left(\mathrm{R}^{2}\right)$ pada dasarnya untuk mengetahui seberapa jauh kemampuan model dalam menjelaskan variasi variabel independen.

Tabel. 4.11

Hasil Uji Koefisien Determinasi $\left(\mathbf{R}^{2}\right)$

\begin{tabular}{|c|c|c|c|c|c|c|c|c|c|}
\hline \multicolumn{10}{|c|}{ Model Summary ${ }^{b}$} \\
\hline \multirow[b]{2}{*}{ Model } & \multirow[b]{2}{*}{$\mathrm{R}$} & \multirow[b]{2}{*}{ R Square } & \multirow[b]{2}{*}{$\begin{array}{l}\text { Adjusted } \\
\text { R Square }\end{array}$} & \multirow{2}{*}{$\begin{array}{l}\text { Std. Error } \\
\text { of the } \\
\text { Estimate }\end{array}$} & \multicolumn{5}{|c|}{ Change Statistics } \\
\hline & & & & & $\begin{array}{c}\text { R Square } \\
\text { Change }\end{array}$ & F Change & df1 & $\mathrm{df} 2$ & $\begin{array}{c}\text { Sig. F } \\
\text { Change }\end{array}$ \\
\hline 1 &, $943^{\mathrm{a}}$ & 890 & ,883 & ,94161 &, 890 & 121,388 & 3 & 45 &, 000 \\
\hline
\end{tabular}

a. Predictors: (Constant), Kinerja Individu, Partisipasi Manajemen, Kecanggihan

Teknologiinformasi

b. Dependent Variable: Efektivitas Sistem Informasi Akuntansi

Sumber : Data Olahan SPSS 26, 2020

Dari tabel 4.11 diketahui bahwa koefisien determinasi (Adjusted $R$ Square) sebesar 0,883 atau sebesar $883 \%$. Hal ini berarti $88,3 \%$ dari variabel perubahan Efektifitas Sistem Informasi Akuntansi bisa dijelaskan atau dipengaruhi oleh variabel Kecanggihan Teknologi Informasi, Partisipasi Manajemen, dan Kinerja Individu. Sedangkan sisahnya sebesar 11,7\% dijelaskan atau dipengaruhi oleh variabel yang lain yang tidak diteliti, seperti sistem Pengendalian Manajemen, Desentralisasi, Saling Ketergantungan dan lain sebagainya.

\subsection{Pembahasan}

1. Pengaruh Kecanggihan Teknologi Informasi Terhadap Efektivitas Sistem Informasi Akuntansi

Kecanggihan Teknologi Informasi memiliki $t_{\text {hitung }}$ sebesar -1.527 sedangkan $t_{\text {tabel }} 2.0128$ sehingga $t_{\text {hitung }}$ $>t_{\text {tabel }}$ dengan signifikan untuk variabel Kecanggihan Teknologi Informasi 0,134 lebih besar dari tarif signifikan 0,05. Maka $\mathrm{H}_{1}$ ditolak sehingga dapat disimpulkan bahwa secara parsial Kecanggihan Teknologi Informasi tidak berpengaruh terhadap Efektifitas Sistem Informasi Akuntansi pada PT. Sinar Mas di Kempas Jaya. Variabel Kecanggihan Teknologi Informasi mempunyai koefisien regresi sebesar 0,110 menyatakan 
bahwa setiap kenaikan Kecanggihan Teknologi Informasi sebesar satu satuan dengan asumsi bahwa nilai variabel lain konstan, maka akan meningkatkan Efektivitas Sistem Informasi Akuntansi akan tetap 0,110.

Hasil ini menjelaskan bahwa jika kecanggihan teknologi mengalami penurunan, maka akan menurun efektivitas sistem informasi akuntansi, dimana kecanggihan teknologi informasi mencerminkan terbatasnya jumlah teknologi yang digunakan, sedangkan kecanggihan teknologi informasi ditandai oleh sifat portofolio penerapan. Kecanggihan teknologi informasi sebagai suatu konstruksi yang mengacu pada penggunaan alam, kompleksitas dan saling ketergantungan teknologi informasi dan manajemen dalam suatu organisasi. Kecanggihan teknologi informasi perlu dipertimbangkan dalam perencanaan dan pengembangan sistem informasi akuntansi karna kecanggihan teknologi informasi yang tinggi akan meningkatkan kualitas informasi.

Penelitian ini tidak sejalan dengan penelitian Pradani, dkk (2017) dimana hasil penelitian menunjukkan kecanggihan teknologi informasi, perlindungan sistem informasi, partisipasi manajemen serta pengetahuan manajer akuntansi berpengaruh positif dan signifikan terhadap efektifitas sistem informasi akuntansi (SIA). Alasan tidak berpengaruh kecanggihan teknologi informasi terhadap efektivitas sistem informasi akuntansi karna dengan adanya teknologi informasi akan menyebabkan ketergantungan, media komputer memiliki kualitas atraktif yang dapat merespon segala stimulus yang diberikan oleh penggunanya. Terlalu antraktifnya, membuat penggunanya seakan-akan menemukan dunianya sendiri yang membuatnya terasa nyaman dan tidak mau melepaskannya. Dengan kecanggihan teknologi saat ini tidak mampu memberikan informasi yang mendukung atau berkualitas karna tikngkat pengetahuan tentang teknologi informasi berkurang sehingga informasi yang didapatkan lambat dan tidak akurat.

\section{Pengaruh Partisipasi Manajemen Terhadap Efektivitas Sistem Informasi Akuntansi}

Variabel Partisipasi Manajemen memiliki nilai $t_{\text {hitung }}$ sebesar 10.242 sedangkan $t_{\text {tabel }} 2.0128$ sehingga $t_{\text {hitung }}>t_{\text {tabel }}$ dengan signifikan untuk variabel Partisipasi Manajemen sebesar 0,000 lebih kecil dari taraf signifikan 0,05. Maka $\mathrm{H}_{2}$ diterima sehingga dapat disimpulkan bahwa secara parsial Partisipasi Manajemen berpengaruh terhadap Efektivitas Sistem Informasi Akuntansi Pada PT.Sinar Mas di Kempas Jaya. Variabel Partisipasi Manajemen mempunyai koefisien regresi sebesar 0,693 menyatakan bahwa setiap kenaikan Partisipasi Manajemen sebesar satu satuan dengan asumsi bahwa nilai variabel lain konstan, maka akan meningkatkan Efektivitas Sistem Informasi Akuntansi akan tetap sebesar 0,693.

Hasil ini menjelaskan bahwa jika partisipasi manajemen tinggi, maka efektivitas implementasi sistem informasi akuntansi semakin tinggi. Keberhasilan implementasi sistem tidak hanya ditentukan pada penguasa teknik belaka, namun faktor perilaku dan individu sangat menentukan kesuksesan implementasi sistem informasi akuntansi dapat mengukur keunggulan daya saing yang dapat diciptakan oleh perusahaan. Peningkatan efektivitas sistem informasi akuntansi memerlukan adanya peran dan partisipasi manajemen dalam mendukung dan pengembangan sistem informasi akuntansi. Sistem informasi akuntansi merupakan bagian yang sangat penting untuk meningkatkan efesien organisasi dan mendukung daya saing dengan menyediakan informasi keuangan dan akuntansi bagi manajemen.

Penelitian ini sejalan dengan penelitian Efendi (2016) yang menunjukkan hasil bahwa pengetahuan karyawan bagi akuntansi, partisipasi manajemen, dan pemanfaatan teknologi informasi berpengaruh positif dan signifikan terhadap efektivitas sistem informasi akuntansi. Alasan berpengaruhnya partisipasi manajemen terhadap efektivitas sistem informasi akuntansi adalah karena dengan keterlibatan manajemen dalam implementasi dan pengembangan sistem informasi akuntansi menjadi satu faktor penting dalam keberhasilan untuk menghasikan kualitas informasi yang tepat waktu, akurat, dan dapat dipercaya.

\section{Pengaruh Kinerja Individu Terhadap Efektivitas Sistem Informasi Akuntansi}

Variabel Kinerja Individu memiliki nilai $t_{\text {hitung }}$ sebesar $-0,917$ sedangkan $t_{\text {tabel }} 2.0128$ sehingga $t_{\text {hitung }}>$ $\mathrm{t}_{\text {tabel }}$ dengan signifikan untuk variabel Kinerja Individu 0,364 lebih besar dari taraf signifikan 0,05. Maka $\mathrm{H}_{3}$ ditolak sehingga disimpulkan bahwa secara parsial Kinerja Individu tidak berpengaruh terhadap Efektivitas Sistem Informasi Akuntansi pada PT. Sinar Mas Kempas Jaya. Variabel Kinerja Individu mempunyai koefisien regresi sebesar 0,142 menyatakan bahwa setiap kenaikan Kinerja individu sebesar satu satuan dengan asumsi bahwa nilai variabel lain konstan, maka akan meningkatkan efektivitas sistem informasi akuntansi akan tetap sebesar 0,142 .

Hasil ini menjelaskan bahwa jika kinerja individu menurun, maka efektivitas sistem informasi akuntansi semakin berkurang. Kinerja individu adalah suatu pencapaian dari tugas-tugas dengan menggunakan teknologi informasi yang mendukung. Berkaca pada memudahkan pekerjaan yang dilakukan manusia, yaitu dengan penggunaan komputer, pengguna teknologi komputer telah memberikan kemudahan bagi karyawan dalam melakukan pemerosesan data.

Penelitian ini tidak sejalan dengan penelitian Rahayu, dkk (2017) yang menjukkan bahwa secara parsial kecanggihan teknologi informasi, partisipasi manajemen, kinerja individu memiliki pengaruh positif dan signifikan terhadap efektivitas sistem informasi akuntansi. Secara simultan kecanggihan teknologi informasi, partisipasi manajemen, dan kinerja indivdu berpengaruh dan signifikan terhadap efektivitas sistem informasi akuntansi. Alasan kinerja individu tidak berpengaruh terhadap efektivitas sistem informasi akuntansi karna berbeda tingkat pendidikan, pelatihan yang diikuti dan sebagainya. Sehingga kurangnya keefektifan dalam suatu sistem untuk menghasilkan informasi-informasi yang tepat dan akurat. 
4. Pengaruh Kecanggihan Teknologi Informasi Partisipasi Manajemen dan Kinerja Individu Secara Simultan Terhadap Efektivitas Sistem Informasi Akuntansi

Kecanggihan Teknologi Informasi, Partisipasi Manajemen dan Kinerja Individu secara simultan mempunyai pengaruh yang signifikan terhadap Efektivitas Sistem Informasi Akuntansi. Hasil penelitian menunjukan bahwa nilai $F_{\text {hitung }}$ sebesar 121.388 sedangkan $F_{\text {tabel }}$ sebesar 2.0128 dengan df pembilang= 3, df penyebut $=45$ dan taraf signifikan $\alpha=0,05$ sehingga $F_{\text {hitung }}>F_{\text {tabel }}$ dan signifikan sebesar $0,000<0,05$. Hasil ini mengindikasikan bahwa Kecanggihan Teknologi Informasi, Partisipasi Manajemen dan Kinerja Individu secara bersama-sama berpengaruh signifikan terhadap Efektivitas Sistem Informasi Akuntansi pada PT. Sinar Mas di Kempas Jaya, sehingga $\mathrm{H}_{4}$ diterima. Hal ini menjelaskan bahwa Teknologi Informasi, Partisipasi Manajemen dan Kinerja Individu secara simultan mempunyai pengaruh yang signifikan terhadap Efektivitas Sistem Informasi Akuntansi. Apabila teknologi informasi, partisipasi manajemen dan kinerja individu mengalami peningkatan, maka akan meningkatnya efektivitas sistem informasi akuntansi, jadi jika kualitasnya tinggi maka akan meningkatkan kualitas informasi.

Penelitian ini sejalan dengan penelitian Efendi (2016), hasil penelitian menunjukkan kecanggihan teknologi informasi, partisipasi manajemen dan kinerja individu secara bersama-bersama berpengaruh positif dan signifikan terhadap efektivitas sistem informasi akuntansi. Alasannya dengan adanya kecanggihan teknologi informasi, partisipasi manajemen dan kinerja individu kurang mempengaruhi efektivitas sistem informasi akuntansi dalam suatu perusaan karna kurang pengendalian dalam penyelesaian pekerjaan dengan teknologi informasi, partisipasi manajemen, dan kinerja idividu yang ada dalam sebuah perusaan sehingga berkurang kefektivan sistem informasi akuntansi.

\section{KESIMPULAN DAN SARAN}

Dari hasil pembahasan yang telah dijelaskan maka peneliti dapat menyusun beberapa kesimpulan sebagai berikut:

1. Secara parsial Kecanggihan Teknologi Informasi tidak berpengaruh terhadap Efektifitas Sistem Informasi Akuntansi pada PT. Sinar Mas di Kempas Jaya, Partisipasi Manajemen berpengaruh terhadap Efektivitas Sistem Informasi Akuntansi Pada PT.Sinar Mas di Kempas Jaya, Kinerja Individu tidak berpengaruh terhadap Efektivitas Sistem Informasi Akuntansi pada PT. Sinar Mas Kempas Jaya.

2. Kecanggihan Teknologi Informasi, Partisipasi Manajemen dan Kinerja Individu secara bersama-sama berpengaruh signifikan terhadap Efektivitas Sistem Informasi Akuntansi pada PT. Sinar Mas di Kempas Jaya

3. Uji koefisien determinasi (Adjusted $R$ Square) sebesar 0,883 atau sebesar $883 \%$. Hal ini berarti $88,3 \%$ dari variabel perubahan Efektifitas Sistem Informasi Akuntansi bisa dijelaskan atau dipengaruhi oleh variabel Kecanggihan Teknologi Informasi, Partisipasi Manajemen, dan Kinerja Individu. Sedangkan sisahnya sebesar $11,7 \%$ dijelaskan atau dipengaruhi oleh variabel yang lain yang tidak diteliti.

\section{DAFTAR PUSTAKA}

Bodnar, George H. and Hopwood, William S., 2014. Accounting Information Systems. Eleventh Edition, Pearson Education

Efendi, Taufik. 2016. Pengaruh Pengetahuan Karyawan Bagian Akuntansi, Partisipasi Manajemen, Dan Pemanfaatan Teknologi Informasi Terhadap Efektivitas Sistem Informasi Akuntansi (Studi Empiris Pada PT Perkebunan Nusantara IX, PG. Mojo, Kabupaten Sragen). Naskah Publikasi. Program Studi S-1 Ekonomi Akuntansi Fakultas Ekonomi dan Bisnis Universitas Muhammadiyah 2016

Ghozali, Iman. 2011. Aplikasi Analisis Multivariate Dengan Program SPSS, Semarang :BP Universitas Diponogoro

Indriantoro Dan Supomo. 2016. Metotologi Penelitian Bisnis.Yogyakarta: BPFE.

Ismail, N .A. dan M. Al-Eqab. 2011. Contingency Factors And Acounnting Information Syestem Design In Jardanian Companies, IBIMA Business Review. Vol. 2011

Pradani, dkk. 2017. Pengaruh Kecanggihan Teknologi Informasi, Perlindungan Sistem Informasi, Prtisipasi Manajemen Dan Pengetahuan Manajer Akuntansi Terhadap Efektivitas Sistem Informasi Akuntansi Pada Hotel Berbintang Di Kabupaten Karangasem. E.journal S1 Ak Universitas Pendidikan Ganesha Jurusan Akuntansi S1.Vol. 7 No. 1.

Rahayu, dkk. 2017. Pengaruh Kecanggihan Teknologi Informasi, Partisipasi Manajemen, Dan Kinerja Individu Terhadap Efektivitas Sistem Informasi Akuntansi (Studi Pada Klinik Rancaekek Kabupaten Bandung). e-Proceeding of Management Vol.4, No.1 Page 501 Prodi S1 Akuntansi, Fakultas Ekonomi dan Bisnis, Universitas Telkom

Ratnaningsih, Kadek Indah. dan Suaryana, I Gusti Ngurah Agung. 2015. Pengaruh Kecanggihan Teknologi Informasi, Partisipasi Manajemen, Dan Pengetahuan Manajer Akuntansi Pada Efektivitas Sistem Informasi Akuntansi. E-Jurnal Akuntansi Universitas Udayana. 6 (1), h:1-16

Safitri, dkk. 2017. Pengaruh Kecanggihan Teknologi Informasi, Partisipasi Manajemen, Dan Kinerja Individu Terhadap Efektivitas Sistem Informasi Akuntansi Studi Pada Klinik Rancaekek Kabupaten Bandung. e-Proceeding of Management. Vol.4 No.1 April 2017 ISSN : 2355-9357.

Sugiono, 2016. Metode Penelitian Bisnis.Bandung:Alfabeta.

Suryani, Pengaruh Kecanggihan Teknologi Informasi, Partisipasi Manajemen Dan Kinerja Individu Terhadap Efektivitas Sistem Informasi Akuntansi 
Suratini, Eka, dkk. 2015. Pengaruh Efektivitas Sistem Informasi Akuntansi Dan Penggunaan Teknologi Informasi Akuntansi Terhadap Kinerja Individual Pada PT. Bank Pembangunan Daerah Bali Kantor Cabang Singaraja. E-Journal S1 Akuntansi Universitas Pendidikan Ganesha Vol 3:1

Sutabri, Tata. 2014. Pengantar Teknologi Informasi, Yogyakarta: Penerbit Andi

Ikatan Akuntan Indonesia. 2012. Standar Akuntansi Keuangan. Jakarta: Selemba Empat. 